\title{
Catalogers' Salaries in Well-Endowed Colleges
}

$\mathrm{T}$ HERE is considerable difficulty in recruiting and retaining cataloging personnel. In order to examine the question of salaries in regard to this problem in college libraries, the writer undertook to survey the situation in forty institutions which are assumed to be endowed adequately. ${ }^{1}$ The World Almanac and Book of Facts for 1946 includes a list of "Colleges with \$2,00o,00o Endowment or More." Only the colleges on this list were circularized, in January-February 1946 , on the problems of (I) salaries, (2) provision for increases, (3) amount of cataloging performed, and (4) faculty status of catalogers. A few technical institutions obviously not comparable with liberal arts colleges were omitted, while two, designated as universities but whose libraries are primarily for undergraduates, were included. This report is not concerned with what is done in poorly endowed, struggling colleges (although some of them doubtless support their libraries better than wealthier institutions), but rather with what is being accomplished by those financially equipped to perform on a high level. Since only a brief questionnaire was sent, replies were almost 100 per cent, although all librarians were neither willing nor able to answer all questions.

1 List of colleges: Agnes Scott, Amherst, Bates, Berea,

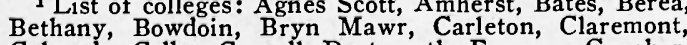
Colorado, Colby, Cornell, Dartmouth, Furman, Goucher, Grinnell, Hamilton, Kenyon, Knox, Macalaster, Mac. Murray, Middlebury, Mills, Mount Holyoke, North Dakota Agricultural, Oberlin, St. Vincent, Simmons, Smith, Swarthmore, Trinity, Tufts, Union, Vassar, Wake Forest, Washington \& Lee, Washington State, Wellesley, Wittenberg, Wooster.
The median salary of the chief, and often only, cataloger in the forty U. S. colleges is $\$ 2100$ a year. The average salary is \$2200. In those colleges which have schedules for increases, the median salary that may be expected by the chief cataloger is $\$ 2500$; the average, $\$ 2600$.

The highest salary at present paid a cataloger in these colleges is approximately $\$ 3700$; the lowest, $\$ 1600$. The highest expected salary is $\$ 4,000$; the lowest, $\$ 1800$. Vacation periods are not uniform.

Of the forty colleges on the list, four have no professional cataloger. For two, this is apparently a temporary situation.

The median number of books and pamphlets (combined) cataloged per year is 3200 . This figure has little value since the statistics range widely from 600 to 30,000 .

The question of faculty status for catalogers, involving vacations, salary scales, club memberships, and sabbaticals was not raised further than to ask the rank of the faculty member whose salary was nearest to that of the cataloger. Thirteen colleges pay their catalogers on a par with instructors, twelve with assistant professors, and one with associate professors. Those replying for the fourteen remaining colleges did not supply data regarding salaries of faculty members.

A more thorough study of this subject is suggested. In the meantime these figures may be of interest to college administrators who want to bring their library staffs in line with the practice in the better institutions. 